\section{What is already known on this topic}

Considerable research has been conducted on Aboriginal health issues in Canada

Whether this research assesses the health needs of the population has never been examined

\section{What this study adds}

Discrepancies exist between research and major health indicators

Research priorities need to be set on the basis of health status and health determinants of the aboriginal population

should be considered, but also the amenability of the health issue to research. There will continue to be a need to strike a balance between targeted research based on an explicit planning process and curiosity driven, investigator initiated research.

TKY has received a senior investigator award from the Canadian Institute of Health Research.

Contributors: TKY is the sole author of this paper.

Funding: No special funding.

Competing interests: None declared.

1 Waldram JB, Herring DA, Young TK. Aboriginal health in Canada: historical, cultural, and epidemiological perspectives. Toronto: University of Toronto Press, 1995.

2 Commission on Health Research for Development. Health research:essential link to equity in development. New York: Oxford University Press, 1990

3 Global Forum for Health Research. The 10/90 report on health research 2001-2002. Geneva: 2002. www.globalforumhealth.org/pages/index.asp (accessed 22 July 2003)

4 World Health Organization. The world health report 2002. Geneva: WHO 2002.

5 Statistics Canada. 2001 Census. Aboriginal peoples of Canada: a demographic profile. Ottawa: Statistics Canada, 2003. www12.statcan.ca/english/ census01/products/analytic/companion/abor/contents.cfm (accessed 22 July 2003)

6 Young TK. The Health of Native Americans: towards a biocultural epidemiology. New York: Oxford University Press, 1994.

epidemiology. New York: Oxford University Press, 1994. Can Med Assoc J 1996;155:1569-78.
8 Bjerregaard P, Young TK. The circumpolar Inuit: health of a population in transition. Copenhagen: Munksgaard International, 1998.

9 Young TK. Are subarctic Indians undergoing the epidemiologic transition? Soc Sci Med 1988;26:659-71.

10 Young TK, Reading J, Elias B, O'Neil JD. Type 2 diabetes mellitus in Canada's First Nations: status of an epidemic in progress. Can Med Assoc J 2000;163:561-6.

11 Harris SB, Gittelsohn J, Hanley AJG, Barnie A, Wolever TMS, Gao J, et al. The prevalence of NIDDM and associated risk factors in native Canadians. Diabet Care 1997;20:185-97.

12 Reading J, Nowgesic E. Improving the health of future generations: the Canadian Institutes of Health Research Institute of Aboriginal People's Health. Am J Public Health 2002:92:1396-400.

\section{Corrections and clarifications}

Correction to a correction: Salt poisoning The correction (BMJ 2003;326:497) to the article by Malcolm G Coulthard and George B Haycock (BMJ 2003;326:157-60) stated that a family court hearing determined that the children had not been salt poisoned. We have been informed by the local authority concerned that this is incorrect. The evidence within the proceedings was not tested and the court did not make any findings of fact or determination.

Chief medical officer's report on the nation's health: Poorly performing doctors are to be dealt with more fairly

In the histogram in this News article by Zosia Kmietowicz we inadvertently got the legend the wrong way round (12 July, p 69). The dark orange shading in fact represents hospital and community doctors, and the pale shading represents general practitioners. The graph therefore shows that among older doctors (aged $\geq 50$ ) more general practitioners than hospital and community doctors were referred to the National Clinical Assessment Authority during April 2001 to December 2002; among younger doctors (aged $<50$ ), more hospital and community doctors were referred.

A healthy view of dying

In the first paragraph in the article by Julia Neuberger (26 July, pp 207-8) the URL for the King's Fund's website was wrong. The correct URL is www.kingsfund.org.uk

\title{
Shocking language
}

Most doctors, regardless of specialty or grade, can probably still recall a list of the causes of shock. This list probably does not include experiencing a psychologically traumatic event. However, when a newspaper reports that a person has "received treatment for shock," the average person (in Britain at least) knows what this means, and it has little to do with dangerously low blood pressure.

Such (mis)use of jargon by the general public is common to all branches of medicine (a headache is painful, an acute headache is even worse, and a chronic headache is practically unbearable), but it seems to be particularly common with psychiatric terminology. This may be because some psychiatric concepts are difficult to grasp, but perhaps it is because we psychiatrists have such a poor understanding (and consensus of opinion) about such concepts ourselves. Furthermore, we periodically change the definitions or invent new ones. Nevertheless, it is striking how often such alternative uses of our specialist language can convey perfectly intelligible clinical information.

Everyone knows what "an alcoholic" is (a person who drinks more than you) or "a neurotic" (a person who worries more than you), but neither diagnosis actually exists according to the current edition of the international classification of diseases (ICD-10), the psychiatrist's bible). Agoraphobia seems to be the (presumably very rare) fear of open spaces such as fields, whereas people who become intensely anxious when away from the safety of their home are "bad with their nerves."

Similarly, if someone tells you that a relative has had a "nervous breakdown," you generally understand what they mean, but you will not find this diagnosis in many psychiatric textbooks. If you inquire further, you may be told that the relative in question had suffered a bout of depression. If this was the diagnosis given by a doctor, then it was probably "clinical depression," but you will not find this in a textbook either. You probably would find "manic depression" in your textbook, but you will no longer find it in the ICD-10, as it has been renamed "bipolar affective disorder."

We doctors like to give grandiose titles to clinical syndromes, if possible in dead tongues such as Latin or ancient Greek (or in German, as is often the case in psychiatry). Despite this, our patients continue to get by perfectly well with their own, parallel, but often more readily understood, versions. Perhaps we should allow ourselves to admit this and try to talk to them in the same language.

Ashley Rule specialist registrar in adult psychiatry, Royal London Hospital (ashleymrule@hotmail.com) 